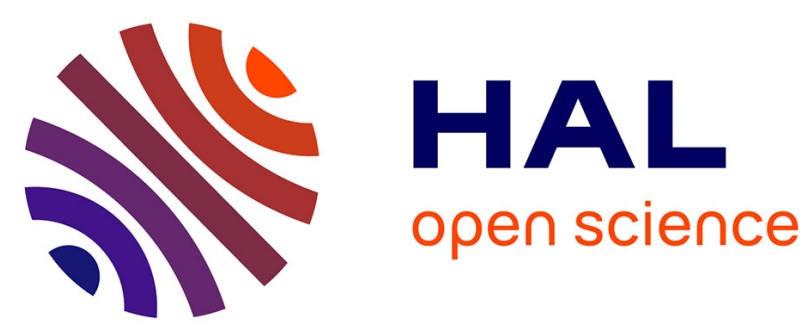

\title{
Impacts of weed management on ladybird (Coleoptera: Coccinellidae) abundance and diversity on resident vegetation in a citrus orchard
}

Marie Rothé, Nina Pelletier, Anna-Morgane Touneji-Catouaria, Christian Bockstaller, Fabrice Le Bellec, Alain Ratnadass

\section{To cite this version:}

Marie Rothé, Nina Pelletier, Anna-Morgane Touneji-Catouaria, Christian Bockstaller, Fabrice Le Bellec, et al.. Impacts of weed management on ladybird (Coleoptera: Coccinellidae) abundance and diversity on resident vegetation in a citrus orchard. International Journal of Tropical Insect Science, 2019, 39 (4), pp.325-331. 10.1007/s42690-019-00055-0 . hal-02460146

\section{HAL Id: hal-02460146 \\ https://hal.science/hal-02460146}

Submitted on 29 Jan 2020

HAL is a multi-disciplinary open access archive for the deposit and dissemination of scientific research documents, whether they are published or not. The documents may come from teaching and research institutions in France or abroad, or from public or private research centers.
L'archive ouverte pluridisciplinaire HAL, est destinée au dépôt et à la diffusion de documents scientifiques de niveau recherche, publiés ou non, émanant des établissements d'enseignement et de recherche français ou étrangers, des laboratoires publics ou privés. 
Impacts of weed management on ladybird (Coleoptera: Coccinellidae) abundance and diversity on resident vegetation in a citrus orchard

Marie Rothé, Nina Pelletier, AnnaMorgane Touneji-Catouaria, Christian Bockstaller, Fabrice Le Bellec \& Alain

\section{Ratnadass}

International Journal of Tropical Insect Science

e-ISSN 1742-7592

Int J Trop Insect Sci

DOI 10.1007/s42690-019-00055-0

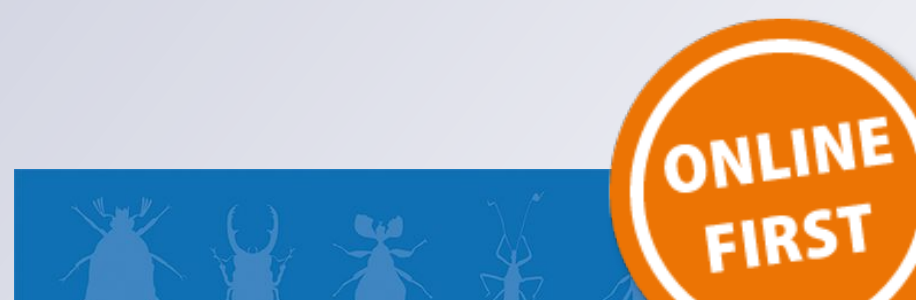

International Journat of

Tropical Insect Scienge 
Your article is protected by copyright and all rights are held exclusively by African Association of Insect Scientists. This e-offprint is for personal use only and shall not be selfarchived in electronic repositories. If you wish to self-archive your article, please use the accepted manuscript version for posting on your own website. You may further deposit the accepted manuscript version in any repository, provided it is only made publicly available 12 months after official publication or later and provided acknowledgement is given to the original source of publication and a link is inserted to the published article on Springer's website. The link must be accompanied by the following text: "The final publication is available at link.springer.com". 


\title{
Impacts of weed management on ladybird (Coleoptera: Coccinellidae) abundance and diversity on resident vegetation in a citrus orchard
}

\author{
Marie Rothé ${ }^{1,3}$ - Nina Pelletier ${ }^{1,3}$. Anna-Morgane Touneji-Catouaria ${ }^{1,3} \cdot$ Christian Bockstaller $^{2} \cdot$ Fabrice Le Bellec $^{1,3}$. \\ Alain Ratnadass ${ }^{1,3}$ (D)
}

Received: 25 April 2019 / Accepted: 7 October 2019

(C) African Association of Insect Scientists 2019

\begin{abstract}
Citrus fruits are markedly affected by aphids on the island of Réunion (France). These pests are generally controlled with pesticides, which have adverse effects on human and environmental health. Furthermore, resident vegetation in orchards is often eliminated with herbicides due to suspected competition with citrus trees for resources. Yet this resident vegetation could serve as a habitat for natural enemies of crop pests, particularly ladybirds (Coleoptera: Coccinellidae), which are well-known aphid predators, thus reducing the need for pesticide treatments. Results of a 2-year study conducted in an experimental citrus orchard, on the impacts of four different weed management treatments on ladybird populations, viz: i) M: hedge-trimmer mowing; ii) T: disk harrow tilling; iii) HM: hammer mill crushing/mulching; iv) H: herbicide spraying are presented. Ladybirds were captured over a 5 week period each year using Malaise-derived flight interception traps. A total of 690 ladybird specimens, belonging to 12 species distributed across four subfamilies, were captured. These were mainly aphidophagous, with Scymnus constrictus Mulsant being largely dominant. There was a significant effect of distance to a field border with diversified vegetation on ladybird abundance and diversity. Ladybirds were also significantly more abundant on tall vegetation cover than on short cover. Although proportionately fewer ladybirds were trapped in the ' $H$ ' treatment than in the other three, there were no clearcut effects of weed management treatments on ladybird abundance. This study nevertheless confirmed the efficacy of interception traps for assessment of ladybird population abundance and diversity. It also demonstrated the potential of these natural enemies as bioindicators of habitat disturbance.
\end{abstract}

Keywords Réunion $\cdot$ Scymnus constrictus $\cdot$ Mowing $\cdot$ Tillage $\cdot$ Mulching $\cdot$ Herbicide $\cdot$ Flight interception trap

\section{Introduction}

With approximately $8400 \mathrm{t}$ of different fruits produced each year over 300 ha, citrus is the third ranking fruit crop on Réunion island after pineapple and banana (DAAF La Réunion, 2014; Agreste, 2015). However, pest pressure due to the island's tropical climate (high temperature and humidity year-round) drastically limits production. Sap-

Alain Ratnadass

alain.ratnadass@cirad.fr

CIRAD, UPR HortSys, F-97455 Saint-Pierre, Réunion, France

LAE, Université de Lorraine, INRA, 68000 Colmar, France

3 HortSys, Univ Montpellier, CIRAD, Montpellier, France sucking insects are the main citrus pests in Réunion, particularly aphids (Hemiptera: Aphididae), such as Toxoptera aurantii (Boyer de Fonscolombe) and Toxoptera citricida Kirkaldy. They cause direct damage via sap uptake or honeydew secretion, resulting in a sooty mould leaf coating affecting photosynthesis (Quilici et al., 2003).

The latter species (T. citricida) is considered more harmful as it is responsible for the transmission of Citrus tristeza virus (CTV), a serious disease that causes relatively rapid progressive citrus tree dieback depending on the rootstock-scion associations (Rocha-Peña et al., 1995). Aphid control is still generally based on chemical treatments in Réunion. However, there is growing public awareness on the need for alternative cropping practices to reduce pesticide use to preserve human and environmental health.

Plant species that constitute the resident vegetation in citrus orchards are generally considered as weeds as they compete 
with the crops for water and/or nutrients. Citrus growers thus generally opt to control this resident vegetation mechanically (tilling) or chemically (herbicide applications), or both (Hanson et al., 2017). These practices may be efficient in the short term but they have an adverse effect on the environment, since herbicide applications lead to a significant decrease in beneficial insects in cropfields, while tilling is conducive to soil erosion (MEA, 2005) and may damage the tree root systems. This study was undertaken in this context with the aim of determining the extent to which different weed management practices affect ladybird populations in the resident vegetation in citrus orchards.

\section{Materials and methods}

\section{Study site and experimental design}

The experimental site was a 0.3 ha citrus orchard (Citrus sinensis x C. reticulata cv. Tangor grafted on Citrange Carrizo) planted in March 2012, after a 2-year spontaneous fallow, at the CIRAD research station, Saint-Pierre, Réunion ( $21^{\circ} 19^{\prime} 25 \mathrm{~S} ; 55^{\circ} 29^{\prime} 18 \mathrm{E} ; 153 \mathrm{~m}$ asl), in a Cambisol soil (IUSS, 2015) (66.4\% clay, $25.6 \%$ silt and $8.0 \%$ sand). Tree rows were planted $6 \mathrm{~m}$ apart with $4 \mathrm{~m}$ on-row spacing.

On the northeastern side, a pre-existing strip of Desmodium intortum (Mill.) Urb. (Fabaceae) separated the orchard from a pre-existing hedgerow of endemic Réunion melliferous plant species, viz: Dombeya acutangula Cav. (Sterculiaceae); Psiadia retusa (Lam.) DC. (Asteraceae); Psiadia dentata
(Cass.) DC.; Indigofera ammoxylus (DC.) and Sida exstipularis (Cav.) (Malvaceae). The block formed by the orchard and adjacent strip and hedgerow was surrounded by a resident vegetation area which, along with the vegetation cover in the $5 \mathrm{~m}$-wide area between rows (Fig. 1), was controlled with a hammer mill. The northeastern side of the orchard was protected by a pre-existing jackfruit (Artocarpus heterophyllus Lam. (Moraceae)) windbreak (Fig. 1).

An experiment was launched in March 2014, under a design with six replications, in view of assessing the effects of four weed management treatments on beneficial arthropods in the resident vegetation cover. The treatments were conducted when consulted neighboring farmers considered that the vegetation cover was too high (70-80 cm high in at least one of the four treatments), with the same timing for all four treatments.

The four weed management treatments compared were: mowing (M); tillage (T); hammer mill (HM), and herbicide (H). Mowing was performed with a hedge-trimmer adapted to cut weeds $10 \mathrm{~cm}$ above soil surface. A disk harrow (Grégoire and Besson $($ ) ) was used once or twice to destroy as many weeds as possible by tilling the upper soil layer only. A hammer mill (SML 155 SEPPI ${ }^{\circledR}$ ) was used to crush weeds at the soil surface level. Hammer mills are actually widely used for weed management in citrus orchards in Réunion. The herbicide treatment consisted of glyphosate applications ( $360 \mathrm{~g} / \mathrm{l}$ at 4 1/ha) to eliminate all weeds.

The four treatments within each replicate [four $65 \mathrm{~m}^{2}$ $(13 \mathrm{~m} \times 5 \mathrm{~m})$ ] plot were pseudo-randomised to allow for heavy agricultural machinery traffic in the inter-rows where
Fig. 1 Experimental design. Grey lines represent tree rows between the four weed management practices: $\mathrm{M}$ (mowing); $\mathrm{T}$ (tillage); HM (hammer mill); and $\mathrm{H}$ (herbicide). The three replicates used for ladybird sampling are indicated with the letters A, B and C. Traps are depicted as triangles, i.e. white for those open to the southeast, shaded for those open to the northwest

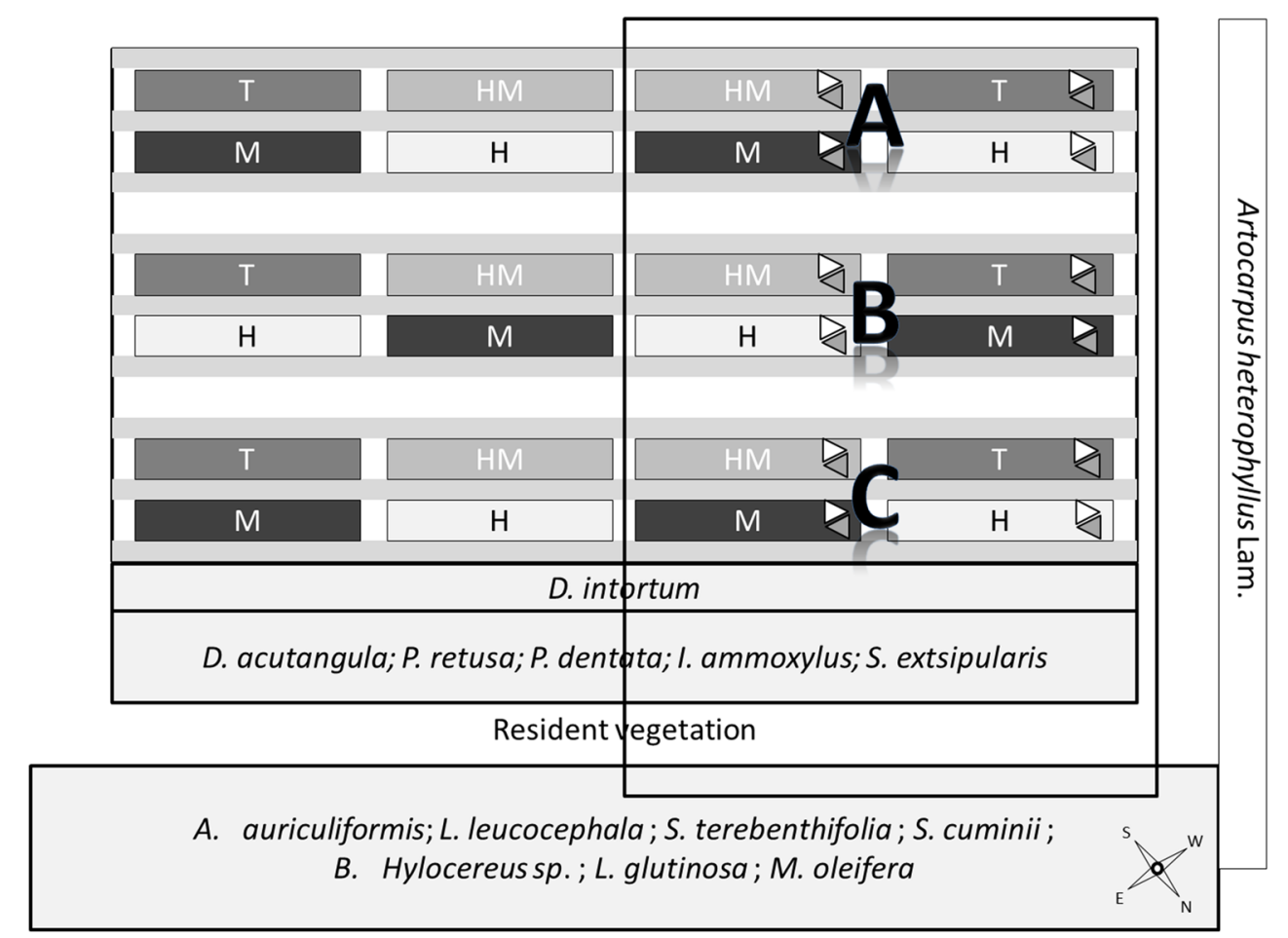


the tillage and hammer mill treatments were conducted. Mowing and herbicide spray treatments therefore had to be carried out in the same inter-rows so that they would not be disturbed by this traffic (cf. Figure 1).

\section{Field instrumentation and observations}

From 20 April to 4 July 2016, and 6 April to 12 May 2017, a pair of unidirectional flight interception traps developed by Sarthou (2009) were placed 'head-to-tail' according to the inter-row orientation (namely opening to the northwest and southeast, respectively) on every elementary plot in the northern half of the experimental design (namely 24 traps on 12 plots: cf. Figure 1). The trapping periods lasted 5 weeks in both 2016 and 2017 . There were three trapping sessions in 2016 and five in 2017. In 2016, traps were activated from 20 to 27 April just before weed management operations, and then from 6 June to 4 July after this operation, on short but growing vegetation cover. In 2017, trapping was carried out throughout the period on high vegetation cover only, and not later on short growing cover. The ladybird population decline following weed management warranted this change, since there were low numbers of individuals which would not allow to discriminate the impacts of weed management modalities. The sampling period could not be extended either because of the pending threat that the whole orchard might have to be eliminated for regulatory reasons due to suspicion of the presence of citrus huanglongbing (greening) disease. Ladybirds were trapped in containers half filled with $70 \%$ ethanol and the contents of each trap were identified and counted using a stereomicroscope (EZ4 LEICA®) after each trapping session.

Identification to the genus or species level was based on the studies of Chazeau et al. (1974), Quilici et al. (2003) and Nicolas et al. (2015). Insect counts allowed calculation of the Coccinellid entomofauna abundance (number of trapped individuals) and diversity (Shannon index $H^{\prime}$ ) (Shannon, 1948).

The Shannon index was calculated by the following formula [1]:

$H^{\prime}=-\sum \mathrm{p}_{i} \log _{2} \mathrm{p}_{i}$

with $\mathrm{i}=1$ to $\mathrm{s}$, where $\mathrm{p}_{i}=$ the probability of meeting a species $i$ in a trap and $s=$ the total number of species encountered in the trap.

\section{Statistical analyses}

All statistical analyses were performed with $\mathrm{R}$ software ( $\mathrm{R}$ Core Team, 2015). To test the effects of the treatments on ladybird abundance and diversity, an analysis of variance (ANOVA) was conducted with a post-hoc Tukey test to adjust $P$-values for multiple comparisons, after checking the data normality (Shapiro test) and variance homoscedasticity (Bartlett test).

Ladybird abundance was expressed as a percentage of the number of trapped individuals over 5 weeks for each pair of traps (i.e. on every elementary plot) to the total number of individuals trapped throughout the experimental orchard. Data from both years (2016 and 2017) were thus used to compare ladybird population distributions and variations across treatments, despite the marked variations in overall abundance between years, notably in conjunction with high variations in aphid abundance on trees. Hence, correlations between the numbers of ladybirds trapped each year were calculated using Pearson's $r$, and cumulative numbers of trapped individuals per plot (i.e. two traps) calculated over a 5-week period.

A Kruskal-Wallis non-parametric test was used to assess the effects of resident vegetation cover development on ladybird abundance because of the non-normality of the data. For this analysis, ladybird abundance was expressed as numbers of trapped individuals for every pair of traps (on every elementary plot).

\section{Results}

\section{Inventory of ladybird species trapped in the resident vegetation cover in the citrus orchard}

A total of 146 ladybird individuals were trapped in 2016, and 544 in 2017 . The ladybird population composition was identified to the species level, except for Nephus spp. the first year. Twelve different species belonging to four sub-families were listed (Table 1).

In 2016 and 2017, respectively, 96.8\%, and $92.5 \%$ of the trapped ladybirds were aphidophagous. Over both years, Scymnus constrictus Mulsant and Exochomus laeviusculus Weise were dominant, respectively accounting for $3 / 4$ and $1 / 6$ of the total number of ladybirds trapped. Despite the between-year differences in abundance, ladybird populations were similar in their distribution throughout the orchard. The correlation between numbers of ladybirds caught in the trapping periods both years was significant (Pearson, $r=0.76$; $P<0.01)$.

\section{Abundance and diversity of ladybirds according to vegetation cover management}

Data normality (Shapiro test: $W=0.9$ ) and variance homoscedasticity were checked for the weed management treatments (Bartlett test: $\chi^{2}=1.354$; d.f. $=3$ ) and blocks (Bartlett test: $\chi^{2}=0.988$; d.f. $=2$ ). Over the two years, proportionately 
Table 1 List and proportions of ladybird species (Coleoptera: Coccinellidae) trapped in the resident vegetation cover in the experimental citrus orchard at Bassin-Plat (Saint-Pierre, Réunion)

\begin{tabular}{|c|c|c|c|c|}
\hline \multirow[t]{2}{*}{ Sub-family } & \multirow[t]{2}{*}{ Species } & \multicolumn{2}{|c|}{ Proportion (\%) } & \multirow[t]{2}{*}{ Diet* } \\
\hline & & 2016 & 2017 & \\
\hline \multirow[t]{4}{*}{ Chilocorinae } & Chilocorus nigritus (Fabricius) & 0 & 1.1 & Aphidophagous \\
\hline & Exochomus laeviusculus Weise & 18.4 & 16.5 & Aphidophagous \\
\hline & Platynapsis capicola Crotch & 0 & 0.6 & Aphidophagous \\
\hline & $\mathrm{sp} 1 * *$ & 0 & 1.1 & $?$ \\
\hline Coccidulinae & Lindorus lophantae (Blaisdell) & 0 & 0.2 & Aphidophagous \\
\hline \multirow[t]{2}{*}{ Coccinellinae } & Cheilomenes sulphurea (Olivier) & 0.8 & 0.4 & Aphidophagous \\
\hline & Psyllobora variegata (Fabricius) & 0 & 0.6 & Mycophagous \\
\hline \multirow[t]{5}{*}{ Scymninae } & Clithostethus arcuatus (Rossi) & 0 & 0.2 & Aleyrodiphagous \\
\hline & Nephus oblongosignatus Mulsant & $3.2 * * *$ & 1.8 & Coccidophagous \\
\hline & Nephus voeltzkowi Weise & $-* * * *$ & 3.9 & Coccidophagous \\
\hline & Scymnus constrictus Mulsant & 77.6 & 73.5 & Aphidophagous \\
\hline & Stethorus histrio Chazeau & 0 & 0.2 & Acariphagous \\
\hline
\end{tabular}

*from Quilici et al. 2003

**Belonging either Brumus (Brumus cf. frater) or Brumoides (Brumoides cf. suturalis) genera; both genera should be subject to revision, since current keys do not allow identification (Raphaëlle Mouttet, com. Pers.). Species belonging to either genus are generally considered as Coccidophagous or Polyphagous (Nicolas et al. 2015)

***Figure for both Nephus spp. since they could not be identified to the species level the first year

$* * * * \mathrm{cf} . * * *$

fewer ladybirds were trapped in the ' $\mathrm{H}$ ' treatment than in the three other treatments (Fig. 2a), but these differences were not significant (ANOVA: $F=2.4$; d.f. $=3 ; P=0.095$ ). Conversely, differences between blocks were significant (ANOVA: $F=7.44$; d.f. $=2 ; P=0.004$ ). Significantly more ladybirds were trapped in Block A, which was the block furthest away from the border of endemic Desmodium and melliferous species, than in Blocks B and C (Fig. 2b).
The same trends were found regarding ladybird diversity (estimated only in 2017) assessed using the ShannonWeaver $H^{\prime}$ index (Fig. 3). Data normality (Shapiro test: $W=0.932$ ) and variance homoscedasticity were checked for both weed management treatments (Bartlett test: $\chi^{2}=$ 2.403; $\mathrm{df}=3$ ) and blocks (Bartlett test: $\chi^{2}=3.112$; d.f. $=2$ ). The weed management treatment effects were not significant (ANOVA: $F=0.06$; d.f. $=3$ ), whereas differences
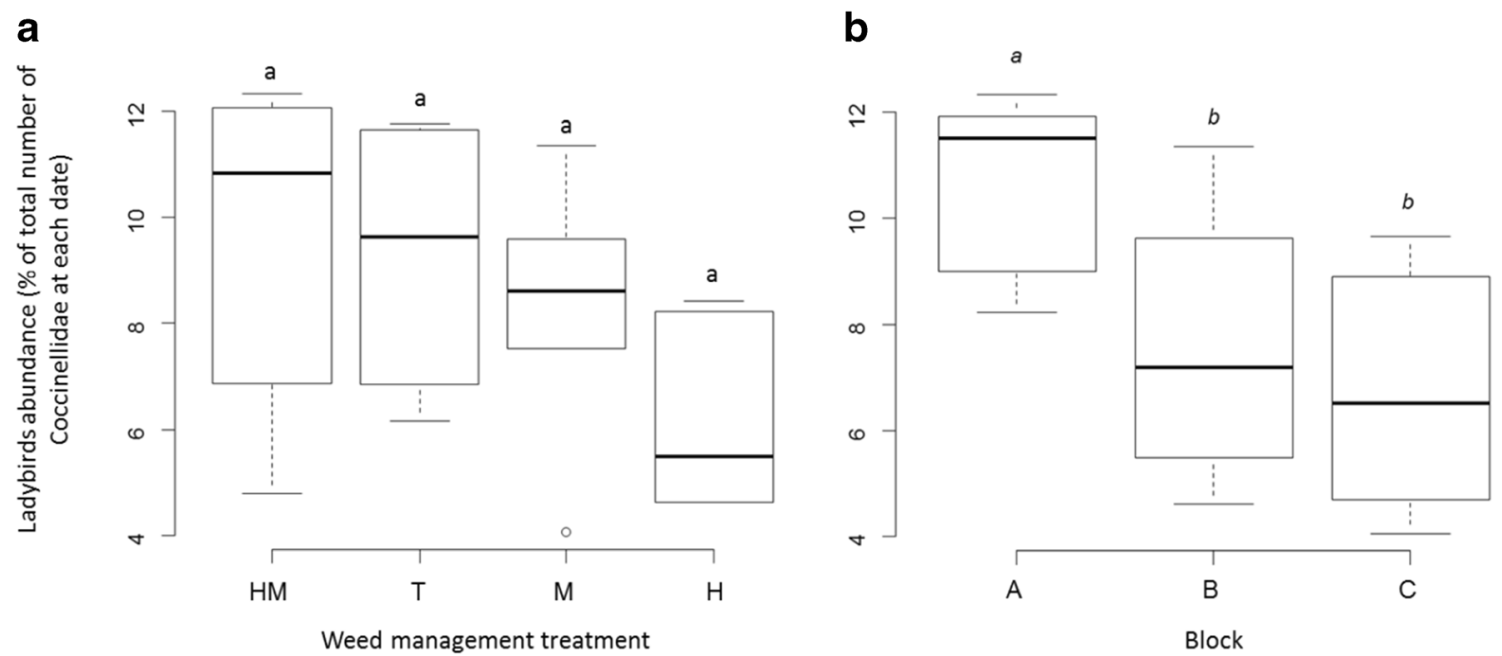

Fig. 2 Mean ladybird distributions in the experimental orchard at Bassin-Plat (Saint-Pierre, Réunion) according to: a. vegetation cover management practices; b. block (= topographical situation). Groups with the same letters are not significantly different at $P=0.05$ according to Tukey's method 
a

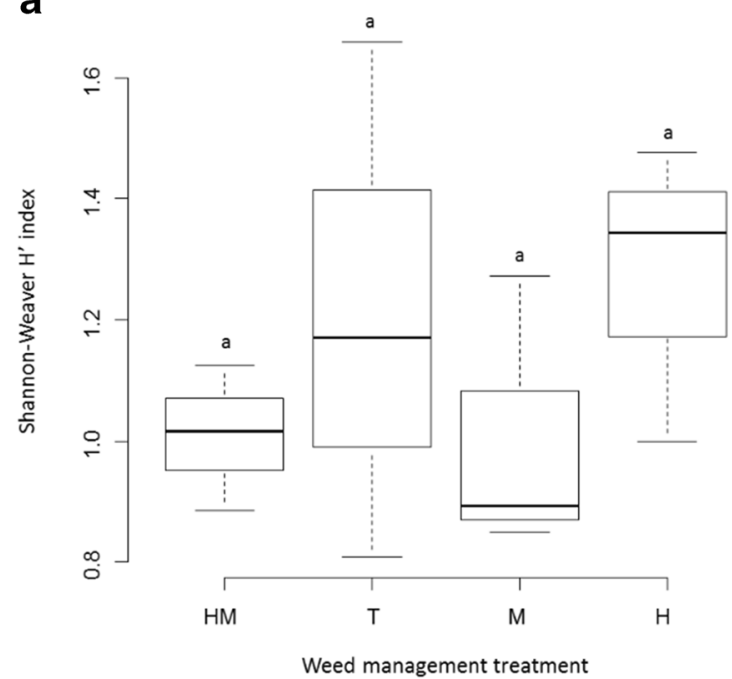

b

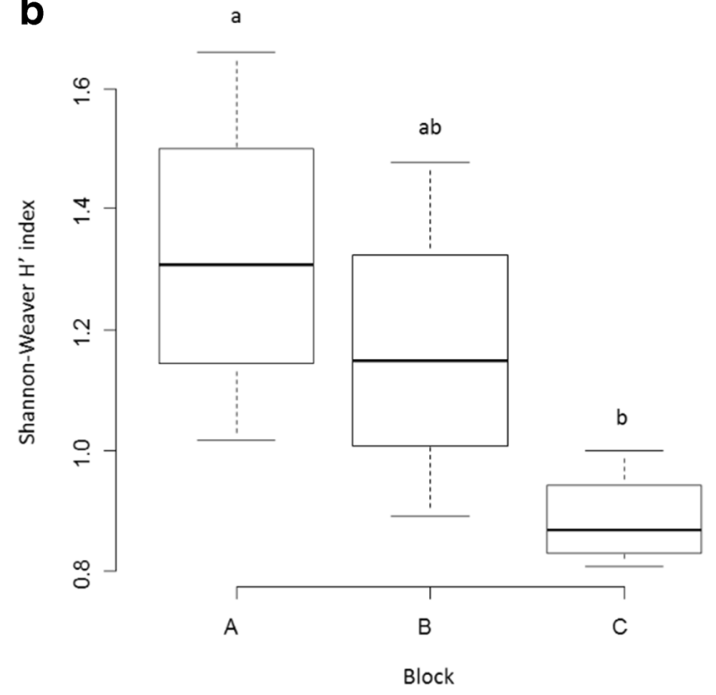

Fig. 3 Distribution of ladybird diversity indices in the orchard resident vegetation cover according to: $\mathbf{a}$. vegetation cover management practice and $\mathbf{b}$. block (=topographical situation). Groups with the same letters are not significantly different at $P=0.05$ according to Tukey's method

between blocks were significant (ANOVA: $F=0.20$; d.f. $=$ 2; $P=0.047$ ). Ladybird diversity was significantly higher in Block A than in $\mathrm{C}$, while this diversity in Block B was intermediate (Fig. 3).

Trapping sessions were conducted before and after weed management in 2016. For each treatment, data analysis findings using the non-parametric Kruskal-Wallis test showed that ladybirds were caught in significantly higher numbers on high vegetation cover than on low or growing cover, both overall $\left(H=21.2 ;\right.$ d.f. $\left.=2 ; P=2.10^{-5}\right)$ and individually for each weed management treatment, with the exception of the HM treatment (Fig. 4) (HM: $H=3.1$; d.f. $=2 ; P=0.21$; T: $H=7.3$; d.f. $=2 ; P=0.03 ; \mathrm{M}: H=5.5$; d.f. $=2 ; P=0.06 ; \mathrm{H}: H=7.4$; d.f. $=$ 2; $P=0.02)$.
Fig. 4 Ladybird population abundance in 2016 according to vegetation cover development and weed management practices. Groups with the same letters are not significantly different according to the Kruskal-Wallis test; $\left.* P<0.05 ;{ }^{\bullet} P<0.1\right)$. 'High' corresponds to high vegetation cover, 'Intermediate' to growing cover and 'Low' to cover immediately after any weed management operation

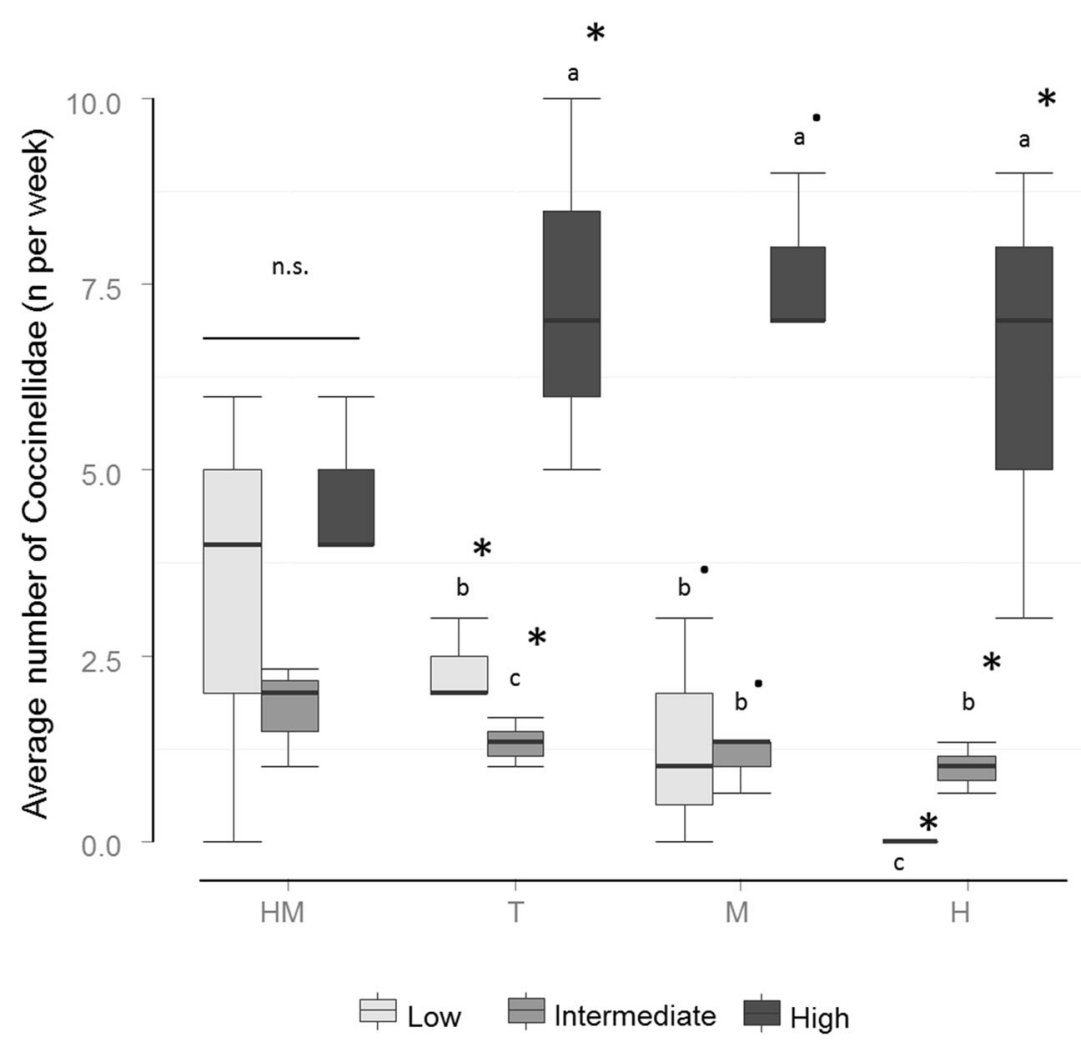




\section{Discussion}

Although proportionately fewer ladybirds were trapped in the ' $\mathrm{H}$ ' treatment than in the three other treatments, no effects of the weed management treatments on ladybird abundance were detected. However, ladybirds were significantly more abundant on tall vegetation cover than on short cover. Each weed management treatment favored different plant species, offering either refuge or alternative trophic resources (pollen, floral or extra floral nectar, alternative prey, honeydew). The effect of vegetation height may have been due to the high Poaceae abundance - the presence of ladybirds on plants of this family has often been reported (Koji et al., 2007; Dong et al., 2012; Diepenbrock and Finke, 2013; Rhino et al., 2016).

The results also showed a decrease in ladybird abundance after weed management operations, which is evidence that the resident vegetation cover was less effective during its regrowth phase. Hammer mill and mowing were found to be the weed management practices that most favored regrowth of Poaceae plants, which are favorable to hosting ladybirds, while herbicide application had the most negative effect on these plant species. It is assumed that herbicide treatment is the most environmentally disturbing practice since it results in virtually bare soil before vegetation cover regrowth. The impact of the various weed management modalities on the floristic composition of vegetation covers is currently the focus of a parallel study that we are conducting, but the results have not yet been analysed. The results of the present study nevertheless suggest that ladybirds may, like Phytoseiidae mites (Le Bellec et al., 2010), be used as bio-indicators of the impact of weed management in citrus orchards, although they are more mobile than mites.

The study also highlighted a significant block effect-a priori an effect of distance to the multi-species hedgerow and adjacent Desmodium strip - on ladybird abundance. This hedgerow provides more permanent habitats and resources for beneficial arthropods like ladybirds, resulting in a 'sink' effect due to the attractiveness of this semi-natural habitat (SNH) for this fauna. The same effect was found with regard to biodiversity, with a lower Shannon-Weaver $\mathrm{H}^{\prime}$ index value in the block adjacent to the multi-species hedgerow than in the most distant block. Other studies have also shown that ladybird abundance in cropfields was less affected by distance to SNHs compared to other groups of beneficials like hoverflies (e.g. Phoofolo et al., 2010; Hatt et al., 2017). Conversely, the 'sink' role of SNHs for other predators (namely earwigs) has also been documented in orchards (Marliac et al., 2015). Our results should nevertheless be confirmed in larger plots (e.g. citrus plantations).

The unidirectional flight interception traps we used (Sarthou, 2009) allowed more local insect trapping than the regular Malaise trap that is generally used for this type of study (Malaise, 1937; Sarospataki and Marko, 1995; Sheikh et al., 2016). Localised trapping enhances the relevance in assessing the impact of a specific management practice on flying insect populations since differences in population level can more easily be ascribed to the immediate environment (Sarthou, 2009). The use of unidirectional flight interception traps was assessed here for the first time under tropical conditions (J.P. Sarthou, pers. com.). They proved suitable for the experimental design and for the target insect family, since 12 ladybird species were captured out of the 24 that have been recorded on the island (Nicolas et al., 2015), and some of them were captured in quite high numbers.

Furthermore, the results showed that fewer insects were captured on low vegetation cover than on high cover, which was consistent with the hypothesis that low cover height provides a more open trap entrance, which favors the interception of insects flying over longer distances. Actually larger plots should be used (e.g. citrus growers' plots) to avoid inadvertently capturing ladybirds coming from outside the plot, particularly from neighbouring plots on which other management practices are used. Note that ladybirds are able to fly a distance of more than $75 \mathrm{~m}$ within a field from its border (Long et al., 1998).

It would also have been of interest to assess the relationship between ladybirds as predators and their prey (sap-sucking Hemiptera). S. constrictus is known to be preferentially aphidophagous, although it may also prey on psyllids and whiteflies (Quilici et al., 2003), while E. laeviusculus is more polyphagous as it preys on all aphid species present on citrus trees, but also on scale insects and mealybugs, and occasionally mites. The abundance of these predators therefore does not necessarily reflect a decrease in aphid populations. The Sarthou trap is not adapted to trapping Hemiptera like aphids or male mealybugs/scale insects due to the generally low proportion of winged forms in their populations. Another trapping or sampling method specifically targetting sap-sucking Hemiptera should be used simultaneously in order to shed light on this relationship.

Finally, from a conservation biological control perspective, it would have been useful to determine the relationship between ladybird populations intercepted in the resident plant cover and those observed on citrus trees (along with their prey).

\section{Conclusion}

The findings of this study support the current trend in favor of implementing alternative cultivation practices to achieve a reduction or even suppression of synthetic herbicide and pesticide treatments. This involves a trade-off between management practices that encourage natural enemies such as ladybirds and the need to avoid competition for water and 
nutrients from the resident vegetation cover, which would adversely affect fruit production.

Acknowledgements The authors are grateful to Raphaëlle Mouttet (Anses, CBGP) for help with ladybird identification and Jean-Pierre Sarthou for his support in designing the interception traps used. We also thank all of the technical staff of the Bassin-Plat research station for implementation of the experiment and field management.

Funding information This study was financially supported by the French Biodiversity Agency (formerly ONEMA), in the framework of the tender 'Biodiversité-Ecophyto' (Agrum'Aide project, 2014-2018).

\section{Compliance with ethical standards}

Conflict of interest The authors declare that they have no conflict of interest.

Disclaimer relating to prior publication The authors declare that an earlier version of the presented work constituted a chapter of the $\mathrm{PhD}$ thesis of the first author, which although accessible from 'https://tel. archives-ouvertes.fr/tel-01896389/file/DDOC_T_2017_0394_ROTHE. pdf $^{*}$, cannot be considered as a prior publication.

\section{References}

Agreste (2015) Statistique agricole annuelle 2014 semi-définitive. Mémento 2015:34

Chazeau J, Etienne J, Fürsh H (1974) Les Coccinellidae de L'île de la Réunion (Insecta Coleoptera). Bulletin du Muséum National d'Histoire Naturelle 210/Zoologie 140, 265-297

DAAF La Réunion (2014) La production fruitière à La Réunion. Agreste La Réunion 92:1-12

Diepenbrock LM, Finke DL (2013) Refuge for native lady beetles (Coccinellidae) in perennial grassland habitats. Insect Conservation and Diversity 6:671-679

Dong ZK, Gao FJ, Zhang RZ (2012) Use of ryegrass strips to enhance biological control of aphids by ladybirds in wheat fields. Insect Science 19:529-534

Hanson BD, Roncoroni J, Hembree KJ, Molinar R, Elmore CL (2017) Weed control in orchards and vineyards, pp. 479-484. In Encyclopedia of applied plant sciences 2 nd edn. (Edited by B. Thomas, B.G. Murray and D.J. Murphy). Academic Press (Elsevier Ltd), Waltham, U.S.A.

Hatt S, Mouchon P, Lopes T, Francis F (2017) Effects of wildflower strips and an adjacent forest on aphids and their natural enemies in a pea field. Insects 8:99

IUSS Working Group WRB (2015) World Reference Base for Soil Resources 2014, update 2015. International soil classification system for naming soils and creating legends for soil maps. World Soil Resources Reports 106. FAO, Rome
Koji S, Khan ZR, Midega CAO (2007) Field boundaries of Panicum maximum as a reservoir for predators and a sink for Chilo partellus. J Appl Entomol 131:186-196

Le Bellec F., Mailloux J., Dubois P., Rajaud A., Kreiter S., Bockstaller C., Tixier M.S. \& Malezieux E. (2010) Phytoseiid mites (Acari) are bioindicators of agricultural practice impact on the agroecosystem functioning: the case of weed management in citrus orchards, pp. 157-158. In Proceedings of Agro 2010: the XIth ESA Congress, 29 August-3 September, 2010 Montpellier, France (Edited by J. Wery, I. Shili-Touzi and A. Perrin)

Long RF, Corbett A, Lamb C, Reberg-Horton C, Chandler J, Stimmann M (1998) Beneficial insects move from flowering plants to nearby crops. Calif Agric 52:23-26

Malaise R (1937) A new insect trap. Entomologisk Tidskrift 58:148-160

Marliac G, Simon S, Mazzia C, Penvern S, Lescourret F, Capowiez Y (2015) Increased grass cover height in the alleys of apple orchards does not promote Cydia pomonella biocontrol. Biocontrol 60:805815

MEA (Millenium Ecosystem Assessment) (2005) Summary for decision makers, pp. 1-24. In Ecosystems and Human Well-being: Synthesis. Island Press, Washington D.C.

Nicolas V., Coutanceau J.-P., Poussereau J. and Gomy Y. 2015. Les Coccinelles de l'Île de La Réunion: Synthèse des données (Coleoptera, Coccinellidae), pp. 58-77. In Contribution à l'étude des Coléoptères de La Réunion: Supplément au Bulletin de liaison d'ACOREP-France "Le Coléoptériste » (Coordinated by Y. Gomy)

Phoofolo MW, Giles KL, Elliott NC (2010) Effects of relay-intercropping sorghum with winter wheat, alfalfa, and cotton on lady beetle (Coleoptera: Coccinellidae) abundance and species composition. Environ Entomol 39:763-774

Quilici S., Vincenot D. and Franck A. (2003) Les auxiliaires des cultures fruitières à l'île de la Réunion. CIRAD. Saint-Denis, $168 \mathrm{p}$

R Core Team (2015) R: A Language and Environment for Statistical Computing. 409-409

Rhino B, Verchere A, Thibaut C, Ratnadass A (2016) Field evaluation of sweet corn varieties for their potential as a trap crop for Helicoverpa zea under tropical conditions. International Journal of Pest Management 62:3-10

Rocha-Peña MA, Niblett CL, Lee RF, Ochoa-Corona FM, Lastra R, Garnsey SM, Yokomi RK (1995) CTV and its aphid vector Toxoptera citricida - threats to citrus production in the Caribbean and central and North America. Plant Dis 79:437-444

Sarospataki M, Marko V (1995) Flight activity of Coccinella septempunctata (Coleoptera: Coccinellidae) at different strata of a forest in relation to migration to hibernating sites. European Journal of Entomology 92:415-419

Sarthou JP (2009) Le piège cornet unidirectionnel, nouveau piège entomologique d'interception. L'Entomologiste 65:107-108

Shannon CE (1948) A mathematical theory of communication. AT\&T Technical Journal 27, 379-423 and 623-656

Sheikh AH, Thomas M, Bhandari R, Meshram H (2016) Malaise trap and insect sampling: mini review. Bio Bulletin 2:35-40

Publisher's note Springer Nature remains neutral with regard to jurisdictional claims in published maps and institutional affiliations. 